\title{
REKONSTRUÁLT SZKÍTA KORI ÍJAKKAL ÉS NYILAKKAL VÉGZETT LŐKÍSÉRLET A DÉDESTAPOLCSÁNY-VEREBCE-BÉRCI KORA VASKORI OSTROM KAPCSÁN
}

\author{
V. Szabó Gábor ${ }^{1}$ - Kiss Attilla ${ }^{2}$ - Tóth Zoltán Henrik ${ }^{3}$ \\ Magyar Régészet 10. évf. (2021), 3. szám, pp. 43-52. https://doi.org/10.36245/mr.2021.3.5
}

Az utóbbi évtizedben egyre több olyan régészeti adat látott napvilágot, amely azt bizonyítja, hogy a Kr. e. 7. század közepén egy kiterjedt, kelet felöl érkezö támadássorozat érte az Északkelet-Magyarország, Nyugat-Dunántúl, Nyugat-Szlovákia és Kelet-Csehország területén élö vaskori közösségeket. Az itteni eröditett települési központok közül ma legalább 20 olyan ismert, amelyeket a falaik mentén elökerült nyilhegyek tanúsága alapján nagyjából egyidőben érhetett jelentös ostrom. ${ }^{4}$

A vaskori támadássorozat leglátványosabb magyarországi bizonyitéka a Bükk-hegység északi peremén található Dédestapolcsány-Verebce-bérc erödített település, ahol az északi sáncok mentén több száz, bronzból öntött, korai szkita típusú nyilhegy került elö.

Nemrégiben új kutatási projektünk részeként egy rekonstruált szkita ijakkal és nyilakkal végzett kisérlet segitségével próbáltunk meg információhoz jutni a verebce-bérci ostrom során kilött nyillhegyek hatékonyságáról, az egykori ostrom lefolyásáról és módjáról.

Kulcsszavak: vaskor, íjászat, Verebce-bérc, kísérleti régészet

\section{AZ OSTROM RÉGÉSZETI BIZONYÍTÉKAI}

A folyóirat egy korábbi számában írtunk arról a 2011-ben zajlott fémkeresőmüszeres felderítésről, amelynek során a lakóteraszokkal tagolt, sáncokkal övezett őskori település északi részén többszáz korai szkíta nyílhegyet fedeztünk fel (V. Szabó, Czajlik \& Reményi 2014; V. Szabó 2018). A nyílhegyek nagy része - mára már csaknem 300 darab - a település déli bejáratát védő sáncfal mentén egy kb. 40-50 méter hosszúságú szakaszon került elő. Újabb kutatásaink során kiderült, hogy a nyílhegyek nemcsak a sáncok mentén szóródnak: 2016-os ${ }^{5}$ és 2020-as évben a sánc mögötti településrész szisztematikus átvizsgálása során 62 darab nyílhegyet találtunk a korábban alig kutatott belső felszíneken (1. kép). A legtávolabbi nyílhegy a sáncok mentén lokalizált leletkoncentráció magjától 540 méterre helyezkedett el. A sáncokon belüli településrész átvizsgált területén a nyílhegyeken kívül számos ép - pl. csónak alakú fibulák

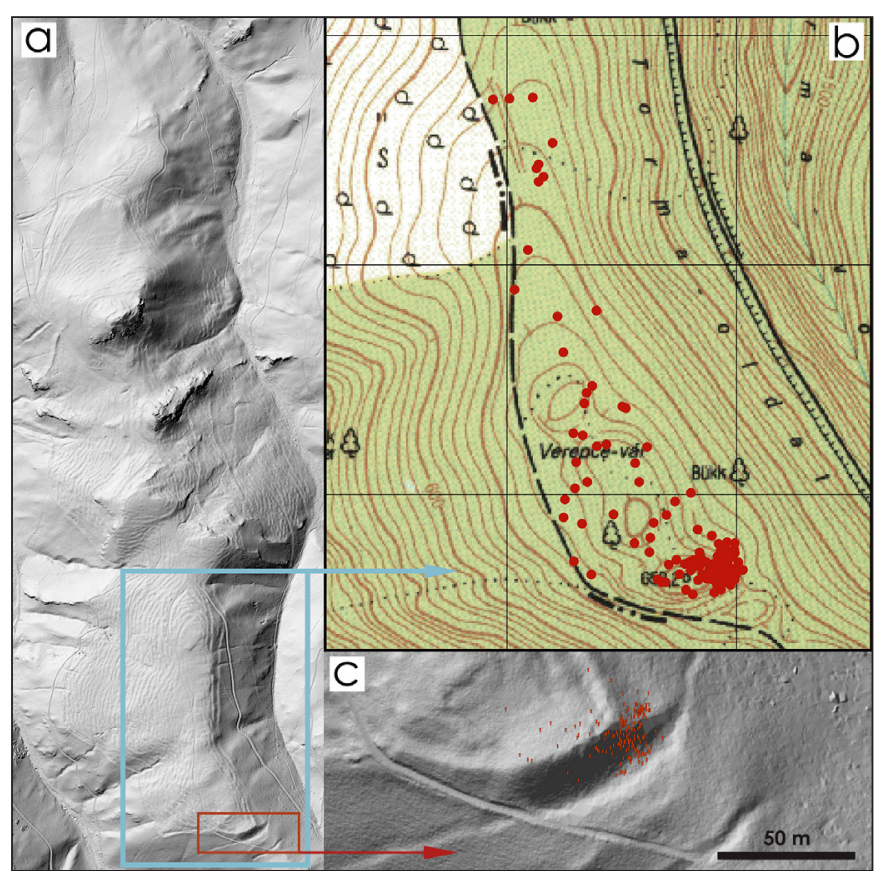

1. kép. a) A Dédestapolcsány-verebce-bérci lelöhelyröl készült LIDAR felvétel. b) A 2018-ban gyüjtött nyilhegyek lelöhelye a déli sánc mögötti településrészen. c). A 2011-ben gyüjtött nyillhegyek szóródása a déli sánctesten

ELTE BTK Régészettudományi Intézet E-mail: vasagab@gmail.com

Zengő Nyíl Történelmi Íjász Iskola,. E-mail: kiss0702@,freemail.hu

Magyar Történelmi Íjász Társaság/Hungarian Historical Archery Society. E-mail: tzhenator@gmail.com

4 Az ostrom horizontot felvázoló kutatások: CHOchorowski 2014, 32-43, Abb. 19, 24; Hellmuth-Kramberger 2017, 584; NovÁK 2017, 197-206, Fig. 9; KLÁPA 2017.

5 A 2016-os kutatások adatainak megismeréséért Bacskai Istvánnak és Bálint Mariannának tartozunk köszönettel. 
V. Szabó Gábor et al. • Rekonstruált szkita kori íjakkal és nyilakkal végzett lökísérlet

(Kahnfibel), állatalakos bronzcsüngő, dísztü (Mehrkopfnadel) stb.-, töredékes és összeégett kora vaskori tárgy is elökerült.

Az eddigi régészeti adatok alapján a következőket tudjuk az ostromról: az íjászok az erődített település legkönnyebben megközelíthető délkeleti sarkát támadták meg, ahol talán egy bástyaszerü emelvény vagy lőállás emelkedhetett a sánc fölé. A szük bevezető út mentén elhelyezkedő íjászok feladata az lehetett, hogy a lőállás védőit koncentrált tüzelésükkel kössék le, amíg egy támadó csapat a bejárati erőd egy másik pontján megpróbál átjutni a falakon. A kilött nyílhegyek jelentős része csorbult és törött volt, ami azt jelezheti, hogy nagy erővel csapódtak valamilyen szilárd felületbe.

Előzetes vizsgálataink arra utalnak, hogy a verebce-bérci vár sáncai mentén kilőtt nyílhegytípusokat főként Erdélyben, a Maros folyó felső folyásának vidékén és a Kárpátoktól keletre eső erdős-sztyeppén, a Dnyeszter folyó középső szakasza mentén megtelepedett, a sztyeppei lovasnomádok jellegzetes fegyvereivel, viseleti elemeivel és lószerszámaival temetkező közösségek használták a Kr. e. 7. század második felében (V. Szabó, Czajlik \& Reményi 2014, 6; Hellmuth-Kramberger 2017, 576-577).

\section{AZ OSTROM ISMERETLEN RÉSZLETEI - A LŐKÍSÉRLET KÉRDÉSFELVETÉSEI}

A rekonstruált íjak és nyílvesszők segítségével végrehajtott lőkísérlettel több, az egykori ostromot érintő kérdésre is szerettünk volna választ kapni.

Az első kérdésünk az volt, milyen messze lehetett a támadó csapatok lőállása a sáncfalaktól? Annak ellenére, hogy a sáncok előtti külső térségeket szisztematikusan átkutattuk, eddig semmilyen régészeti adathoz nem jutottunk a támadók helyzetével kapcsolatban.

Második kérdésünk a támadók íjainak lőtávolságára vonatkozott: milyen messze löhettek be nyilakat a megtámadott településre, és a sáncoktól távolabb előkerült nyílhegyek utalhatnak-e arra, hogy az ostromlók bejutottak az erődítésen belüli részekre?

Harmadik kérdésünk azt vizsgálta, milyen felületbe csapódhattak be a támadók nyílhegyei és mi is okozhatta a különbözö deformációkat. A lelöhelyen talált hegyek közt nagyon sok sérült nyílhegy került elö - egy részük törött volt, egy részük pedig elgörbült, de voltak összeolvadt darabok is (2. kép), ami talán arra utal, hogy a támadók az ostrom során a sáncok felgyújtásával is próbálkozhattak.

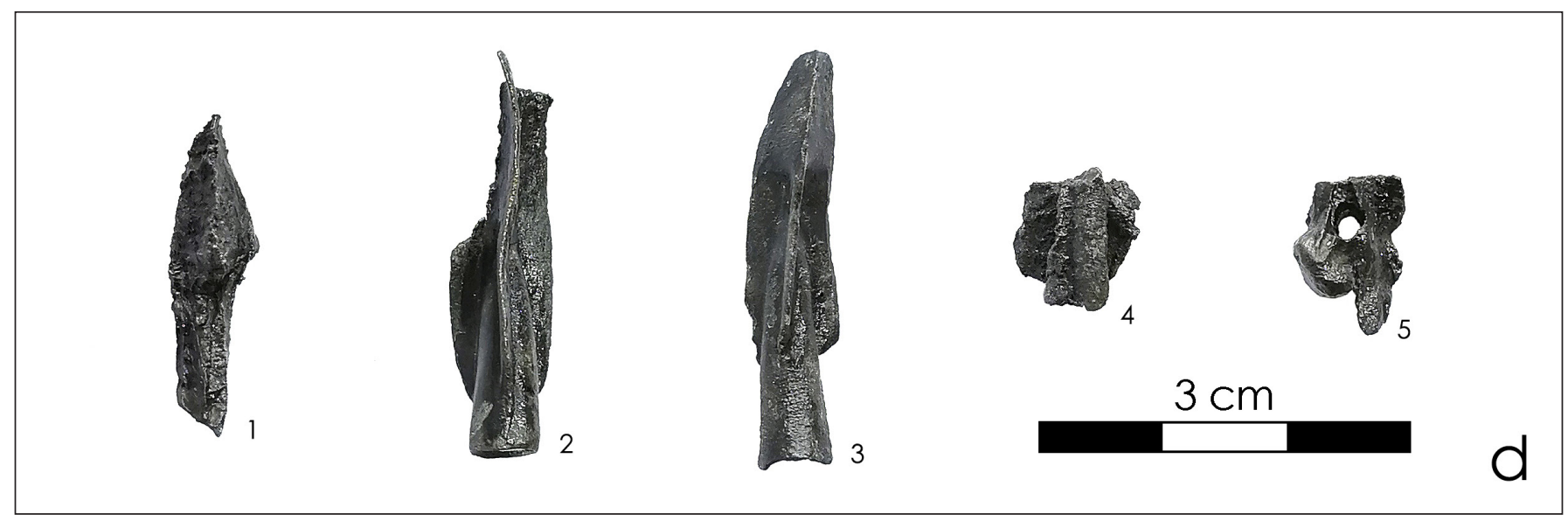

2. kép. Megolvadt és sérült nyillhegyek a sánctest környékéröl

\section{A KÍSÉRLET LEFOLYÁSA ÉS MÓDSZEREI}

A kísérlet három fázisban zajlott: elsőként elkészültek az íjak és a nyilak, illetve a különböző célfelületek. Ezt követően a nyílhegyek lelőhelyén végzett tesztlövések során az íjak lőtávolságát, illetve a támadók lehetséges helyzetét próbáltuk meg tisztázni. Harmadik lépésben azt vizsgáltuk, hogy a különböző felületekre, különböző távolságokból és különböző erejü íjakból leadott lövések milyen deformációt idéznek elő a nyílhegyeken. 


\section{A NYÍLVESSZŐK ELKÉSZÍTÉSE}

A lövéstesztekre a Verebce-bércen elökerült nyílhegytípusok (3. kép) közül hármat választottunk ki: az Anja Hellmuth ${ }^{6}$ által „1 C” típusként meghatározott, kétélü, hexagonális pengéjü nyílhegyet, a „,2 F” típust, amely egy tüskével ellátott, külső köpüs, háromélü nyílhegy, valamint a ,2 B” típust, amely egy belső köpüs, rövid, háromélü nyílhegyforma (Hellmuth 2010, 25-27, 81-86, 63-68; 4. kép). Minden típusból kilenc darabot öntöttünk viaszveszejtéses eljárással, 12\%-os óntartalmú bronzból. ${ }^{7}$

A nyílvesszők közül néhányat 50 centiméteresre készítettünk, de a legtöbbet a többszöri felhasználás és könnyebb javításuk érdekében 60-80 centiméteresre formáztuk. A vesszők hosszúságának tervezésénél a görög vázaképek szkíta íjászábrázolásait (LuK'JASHKo 2015; DARAGAN 2020a, 165-167) és sztyeppi régió szkíta régészeti leletegyütteseiből ismert méreteket próbáltuk meg követni. A régészeti leletek közül a Kr. e. 4. század második negyedére keltezett bulgakovói tegez ép nyílvesszőit tekintettük irányadónak, amelyek $42-53 \mathrm{~cm}$ hosszúságúak és $0,5 \mathrm{~cm}$ átméröjüek voltak (DARAGAN 2020a, 160). Mérhető nyílvesszőhosszúságra jól használható példáink voltak még az aržani 2. kurgán nyílveszszői, amelyek hossza 45-65 cm, átmérőjük pedig 0,6-0,8 cm között volt (Čugonov, PARzINGER \& Nagler 2010, 43, 47, Abb. 52, Taf. 25-26, 47-48; Godehardt \& Schellenberg 2010, 218).

Az eurázsiai sztyeppe régióban talált nyílmaradványok anyaga széles skálán mozog: egyaránt ismertek nyírfából, nyárfából, füzből, kőrisböl,

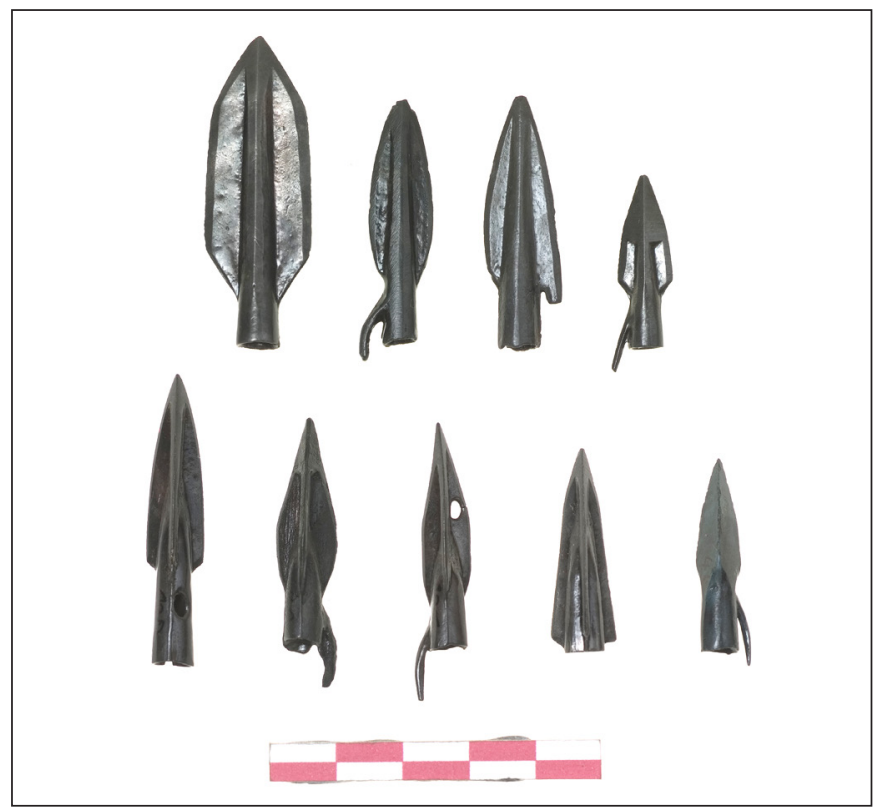

3. kép. A lelöhelyröl elökerült föbb nyílhegytipusok

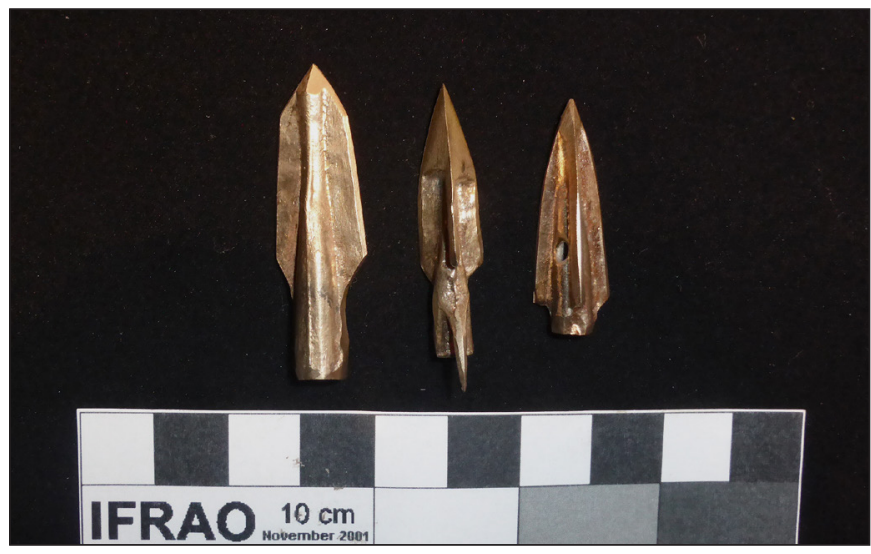

4. kép. A lökísérletre öntött három különbözö nyilhegy típus fenyőböl és tamariszkuszból készített darabok (pl.

TAYLOR et al. 2021, 7, Fig. 4). Az általunk immár három magyarországi lelöhelyen is nagyobb szériában talált korai szkíta nyílhegyekben eddig nem sikerült a vesszőhöz tartozó famaradványt megfigyelni, ezért a kísérletünkbe bevont nyílvesszők fenyőből és hársból készültek. A vesszők dongás kialakításúak voltak, vagyis a hegytől kiindulva az átmérőjük a második harmadig növekszik, majd a nyílajak (nock) - a vessző végén kialakított függőleges vájat, amelybe az íj idegét akasztják - irányába ismét csökkenni kezd; a nyílajak bevágása előtt ismét kiszélesedik. A vesszők legnagyobb átmérője 1,0 cm, legkisebb átmérőjük pedig $0,8 \mathrm{~cm}$ volt, súlyuk pedig 20 és 44 gramm közt mozgott.

A Verebce-tetőn talált bronz nyílhegyek köpüje a szkíta nyílhegyek köpüjéhez hasonlóan meglehetősen szük, vagyis a fatestet keskeny kúp alakúra kellett faragni, ami megnövelte a törés veszélyét, ezért a hegy tövénél enyvezett szarvasínakkal kellett megerösíteni. Ilyen megerösítés került a tollak hegy felőli végére és a nyílajak tövéhez is. A tollak pulyka- valamint vadlúd-szárny evezőtollából készültek. A nyílhegyeket bőrenyvvel rögzítettük a nyílvesszőkhöz (5-6. kép). A lökísérletre összesen 27 darab nyílvesszőt készítettünk.

\footnotetext{
6 A közép-európai kora vaskori ostromok során használt keleti típusú nyílhegyek klasszifikációját Anja Hellmuth Kramberger végezte el. Munkánk során az általa meghatározott tipológiai és kronológiai kategóriákat használtuk (HELLMUTH 2010).

A nyílhegyek készítésének módjáról ld. Daragan \& Romanenko 2021.
} 
V. Szabó Gábor et al.・Rekonstruált szkita kori ijakkal és nyilakkal végzett lökísérlet

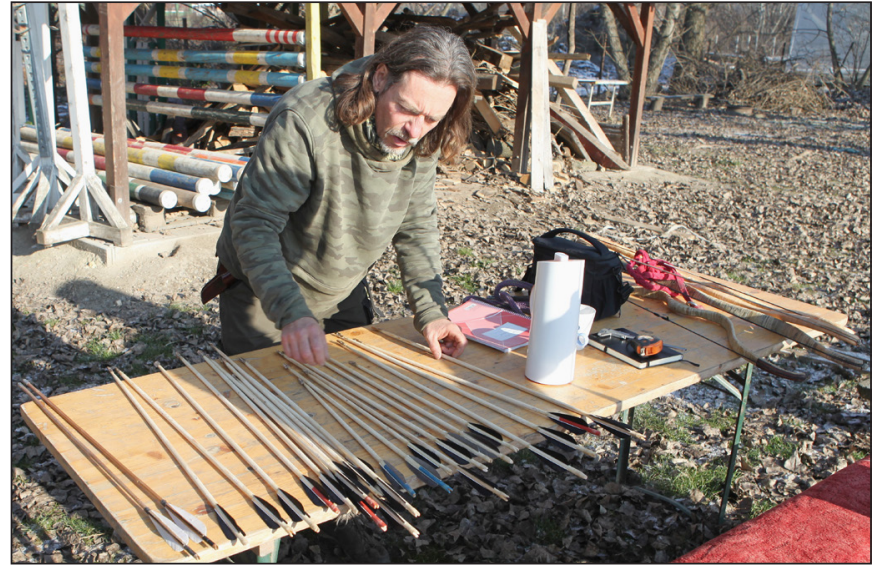

5. kép. A lökisérletre elökészitett ijak és nyílvesszők

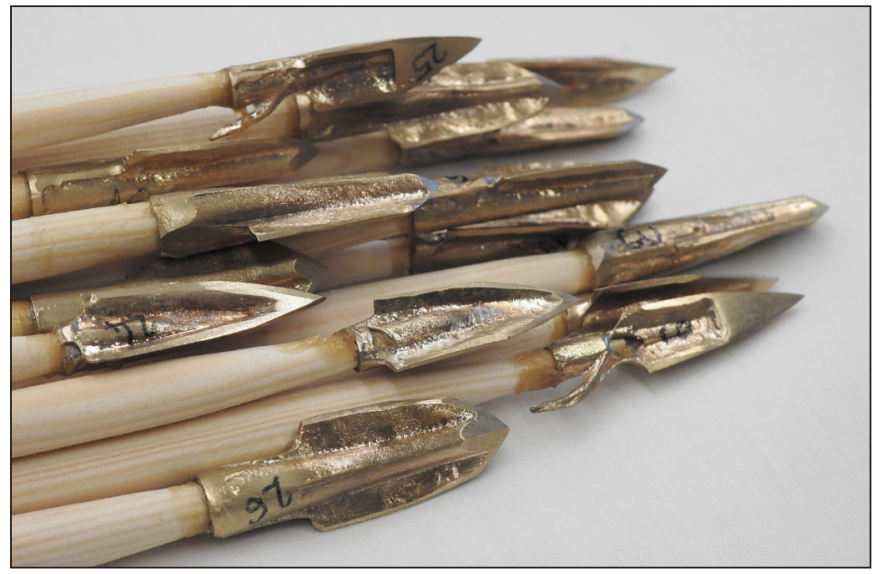

6. kép. A lőkisérletek során használt nyílvesszők

\section{A KÍSÉRLET SORÁN FELHASZNÁLT ÍJAKRÓL}

A lövéseket régészeti leletek alapján rekonstruált, korhű szkíta íjakból adtuk le a különböző célfelületekre és célokra. A kísérlet során három darab, eltérő szerkezetű szkíta stílusú íjat használtunk (GODEHARDT 2009; Godehardt \& Schellenberg 2010; LukJasko 2015; LukJasko 2016; Daragan 2020b; 7. kép). Az íjak elkészítése tradicionális módon történt, összeállításuk során kizárólag természetes módon keletkezett, illetve elöállított anyagok lettek felhasználva: pl. fa, szaru, állati inak, valamint a ragasztáshoz bőr- és halhólyagenyv.

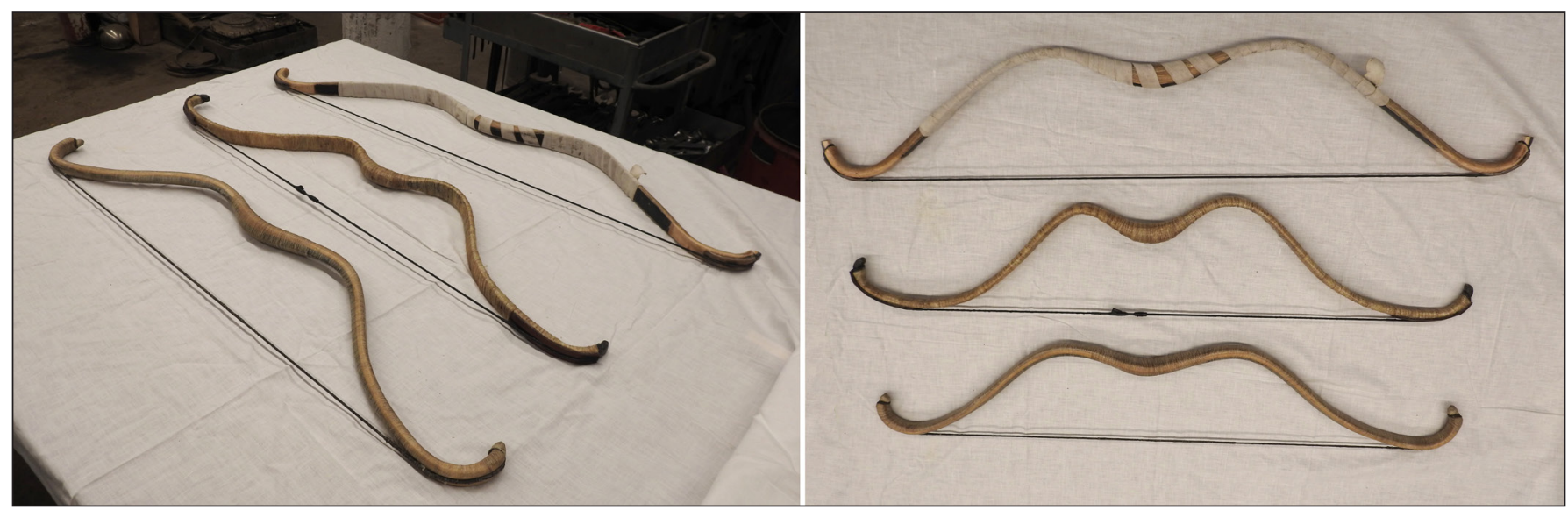

7. kép. A lökísérlet során használt szkita típusú íjak

Az 1. íj a csekély számú észak-pontuszi íjmaradványok egyikének, a vishnevkai íjnak a másolata (ANDRUH 1988, 164-165, Ris. 4.1-2). A korai szkíta harcos sírjából származó maradványok alapján rekonstruált íj egy belső famagból és a ráragasztott szaru és ín rétegekből készült, és nyírfakéreg borítást kapott. Készítője Kiss Attila volt.

A 2. íj modellje a délnyugat-szibériai Aržan 2. kurgán 5., központi sírjában töredékes állapotban megmaradt íj volt, amely több farétegből állt, hasonlóan az obi-ugor íjakhoz és a mai laminált íjakhoz (GoDEHARDT \& SchellenBerg 2010). ${ }^{8}$ Ennek megfelelően a rekonstruált fegyver több, egymásra ragasztott falapból, és az erre felvitt szaru-ín rétegekböl lett összeépítve. Az íjat Rudolf Faustmann készítette, amelyet azután Kiss Attila javított ki és alakított át.

A 3. íj a kínai Xinjiang tartományban, Subashi lelöhelyen elökerült, rendkívül jó állapotban megőrződött, a Kr. e. 5-3. századra keltezett íj (Dwyer 2003; Riesch \& Rutschke 2009; Karpowicz \& Selby 2010)

Az aržani íjat elemző E. Godehardt szerint (Godehardt et al. 2009, 32; Godehardt \& Schellenberg 2010, 218) ez az íj valószínüleg használhatatlan volt és temetkezési mellékletként elhelyezett szimbolikus darab lehetett. Véleményünk szerint nem zárható ki, hogy az íj valójában funkcionáló eszközként került a sírba, de előkerülésekor már meglehetősen leromlott állapotban volt és hiányzott róla mindkét reflex, vagyis visszahajló rész. 
V. Szabó Gábor et al. • Rekonstruált szkita kori íjakkal és nyilakkal végzett lökísérlet

mintájára lett felépítve. Az íj magja gőzölve formára hajlított kökényfa- és vízibivalyszaru-csíkokból áll, tokhólyag enyvvel lett összeragasztva, hátára két marhaínréteg került. Az íj finom szerkezete teljes hosszán szoros ínbandázzsal lett megerősítve, majd a nedvesség elleni védelméül vízhatlan nyírfakéreg borítást kapott (KIss 2020, 954-955). Ennek a darabnak a készítője Pári Vilmos volt (8. kép).

A kísérlet során használt íjak erőssége a következő volt: az 1. íj $60 \mathrm{~cm}-\mathrm{en}(23,7 \mathrm{col}) 55$ font, a 2 íj $60 \mathrm{~cm}$-en $(23,7 \mathrm{col}) 72 \mathrm{font}$, a 3 . íj pedig $60 \mathrm{~cm}$-en (23,7 col) 101,75 font. A 2. íj a terheléses kísérlet közben a $-10 \mathrm{C}^{\circ} \mathrm{os}$ hidegben a löállványon eltört. $\mathrm{Az}$ ijak teljesítményét befolyásolhatta egykori használójuk gyakorlottsága is: ezt bizonyítja, hogy a nyílhegyteszthez használt 3. íjat Tóth Zoltán Henrik kb. 17 colra (62, 48 font), Kiss Attila kb. 21 collra (88, 44 font) tudta kifeszíteni.

$\mathrm{Az}$ íjak rekonstrukciója esetünkben több prob-

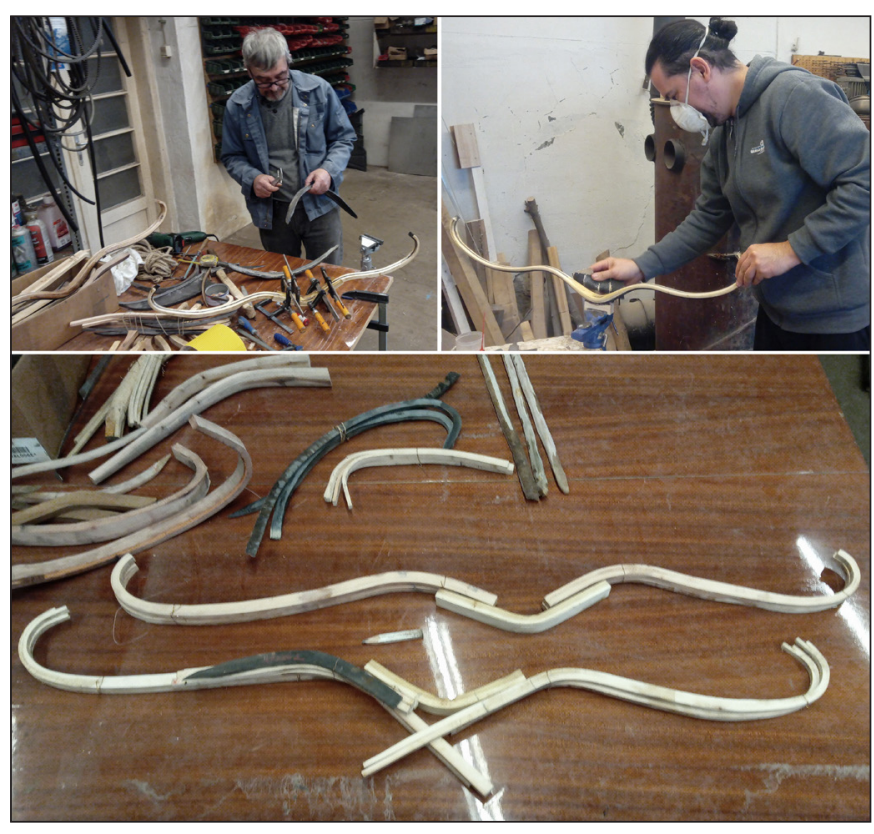

8. kép. A kísérlet során használt szkita-típusú ijak elkészitésének különbözö munkafázisai lémát is felvetett: egyrészt a mintául vett eredeti íjak térben jóval távolabbi területekröl származnak, mint a nyílhegyeink, ezért nem zárható ki, hogy a dédestapolcsányi ostromlók más szerkezetủ íjakat használtak. Ez a probléma a lőkísérletek során is megmutatkozott, mivel azt tapasztaltuk, hogy a kísérletben használt íjak húzóerejük alapján nem kompatibilisek valamennyi nyílvesszővel, ami miatt a könnyebb, rövidebb nyilakkal nem lehetett pontos lövéseket leadni. A pontos lövések leadásához az íj erejének összhangban kell lennie a nyilak súlyával és anyaguk rugalmasságával - esetünkben, úgy tünik, ez a feltétel nem valósult meg.

\section{A CÉLFELÜLETEKRE LEADOTT LÖVÉSEK}

A kísérlethez használt három eltérő típusú, a késő bronzkori és kora vaskori erődítések fö alkotóelemeit reprezentáló célfelületet készítettünk. Ezekkel az volt a célunk, hogy a rájuk leadott lövésekkel vizsgáljuk meg, hogy a különböző anyagokba becsapódott nyílhegyek milyen sérüléseket mutatnak, és hogy a sérülések módja utalhat-e arra a felületre, amibe a nyílhegyek becsapódtak.

Elsőként egy keményfa rönkökböl összerakott, szálfákból épített paliszádot idéző célt készítettünk. Ezt követően összeállítottunk egy vastagabb fagalylyakból fonott szerkezetet, ami a sövényfonatos szerkezetü falakat utánozta. Harmadik célfelületünk egy földdel és apró kőtörmelékkel megtöltött textil zsák volt, amelyben döngöléssel tömörítettük össze a beöntött anyagot. Ezzel a kazettás szerkezetủ favázas sánctestek feltöltését szerettük volna modellezni. A fonatos szerkezetü célfelületet néhány lövés során nyers, enyhén nedves marhabörrel is lefedtük, amelylyel feltételezésünk szerint az ilyen gyúlékonyabb szerkezeteket védhették gyújtónyilak ellen (9. kép).

Mivel a célunk a nyílhegyek sérülésének vizsgálata volt, a célfelületekre a lövéseket 8 méter távolságból

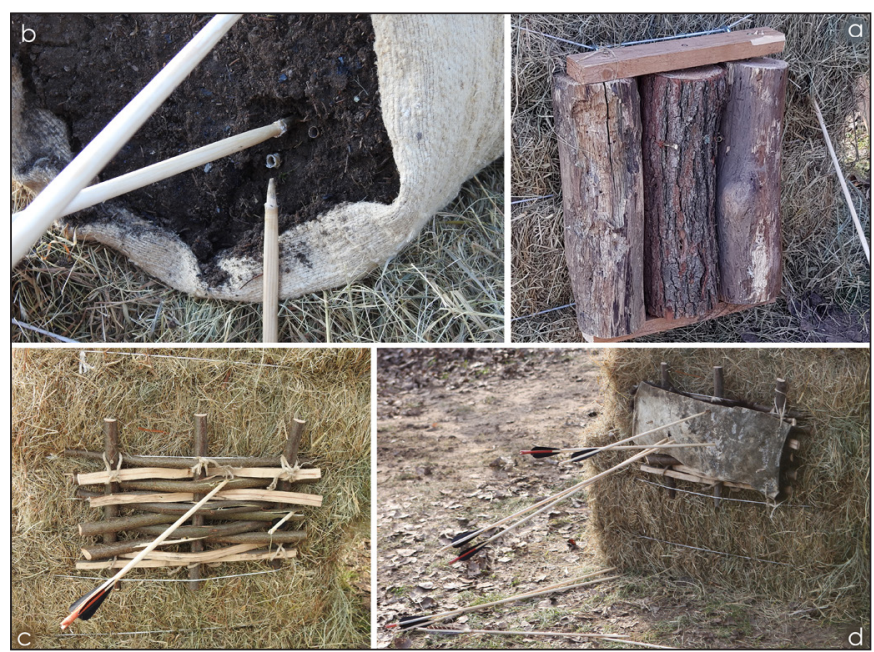

9. kép. A lőkisérlet során használt célfelületek: a) paliszádot időző keményfarönkök; b) tömörített földés kötörmelék; c) faágakból fonott felület; d) az ágfonatos felület marhabörrel fedve 
V. Szabó Gábor et al. • Rekonstruált szkita kori íjakkal és nyilakkal végzett lökísérlet

adtuk le. A kis távolságról való lövés oka az a fentebb már említett probléma volt, hogy a kísérletben használt íjak túl erősek voltak a használt nyilakhoz képest és azokat nagyobb távolságról kilőve félrevitték.

A különböző korú íjakkal végrehajtott lőkísérleteknél a Magyar Történelmi Íjász Társaság és a Zengő Nyíl Egyesület lőállványt használ a pontosabb dokumentálás és az ijak teljesítményének mérése érdekében (10. kép). A kísérlet elején derült ki, hogy ez az állvány a szkíta íjrekonstrukciók stabil rögzítésére nem alkalmas, mivel annak befogó-

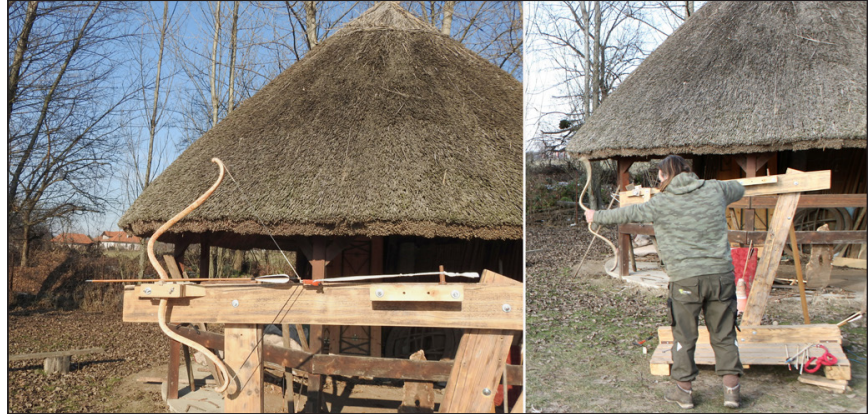

10. kép. A célfelületekre kézböl és löállványról leadott lövések módja modulja elsősorban merevszarvú és oszmán szaruíjak markolatának stabil rögzítésére lett kialakítva. Ezen íjak markolata oldalról és a hasi rész felől az íj idegével többé-kevésbé párhuzamos, míg a szkíta íjaké ívelt, erősen domborodó és a fentebb említett íjtípusokhoz képest szélesebb is. Az állvány használhatatlan volta miatt a lövéseket végül kézből kellett leadni.

\section{TEREPI LŐKÍSÉRLET}

A terepi lőkísérletre 2021. januárjában került sor Dédestapolcsány-Verebce-bérc lelőhelynek azon a részén, ahol az ostrom nyomait lokalizáltuk. A lövéseket nyílhegyek zömét rejtő sáncszakasz előtti területekről adtuk le az erődítések irányába. Az egykori sáncok a feltételezett lőállás felett kb. 15-20 méterrel helyezkednek el (11. kép).

Korábbi kísérleteinkből (KISS 2020, 956-958) már tudtuk, hogy a szkíta stílusú íjak maximális lőtávolsága 130-140 méter, és hogy a távolsági lövések esetén legideálisabb a $45^{\circ}$-os szögben tartott kilövendő nyíl. A verebce-tetői terepi lőkísérlet során - mivel az ostromlók feltételezett helye jóval alacsonyabban volt a védőkénél - nem lehetett ezt az ideális szöget tartani (12. kép). Emiatt a legtöbb célzott lövés az ideálisnál nagyobb szögben történt. Nehezítette a kísérletet az is, hogy a helyszínen álló szálfák nem biztosítottak a nyilak számára akadálytalan röppályát.

A terepi kísérlet során legtávolabbi lövésünk 110 méter távolra szállt, de a szabadon kilött nyílvesszők zöme 80-90 méter körüli távolságra csapódott be. Azzal mindenképpen számolnunk kell, hogy az egykori támadók fegyvereinek lötávolsága valószínúleg jóval meghaladta az általunk felhasznált íjakét. ${ }^{9}$ Ennek az oka egyrészt az egykori íjászok gyakorlottsága lehetett, másrészt az a már említett probléma, hogy a nyilaink húzóereje nem volt összehangolva a kilött nyílvesszők méretével és súlyával. A terepi lőkísérlet idején $-15 \mathrm{C}^{\circ}$-os hőmérséklet volt, ami szintén befolyásolhatta az íjak müködési tulajdonságait.

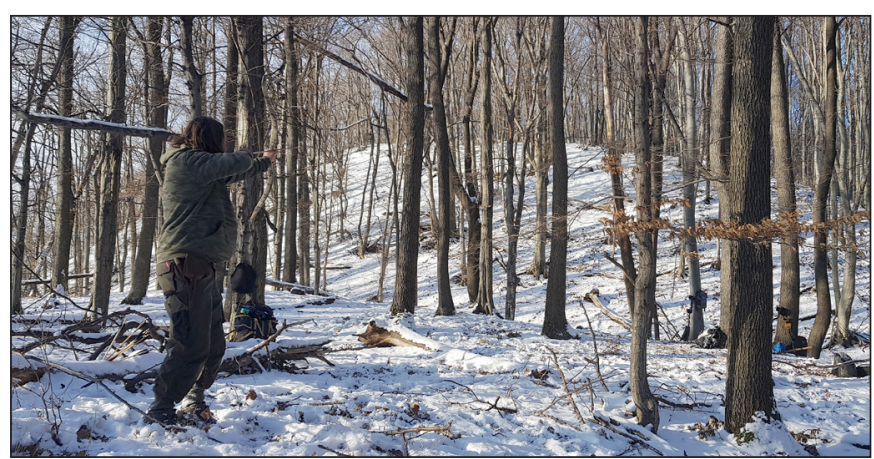

11. kép. A terepi lőkisérlet helye a Dédestapolcsány-verebce bérci sánc elöterében. A lövések a támadók feltételezett állásából a sánc felé irányultak

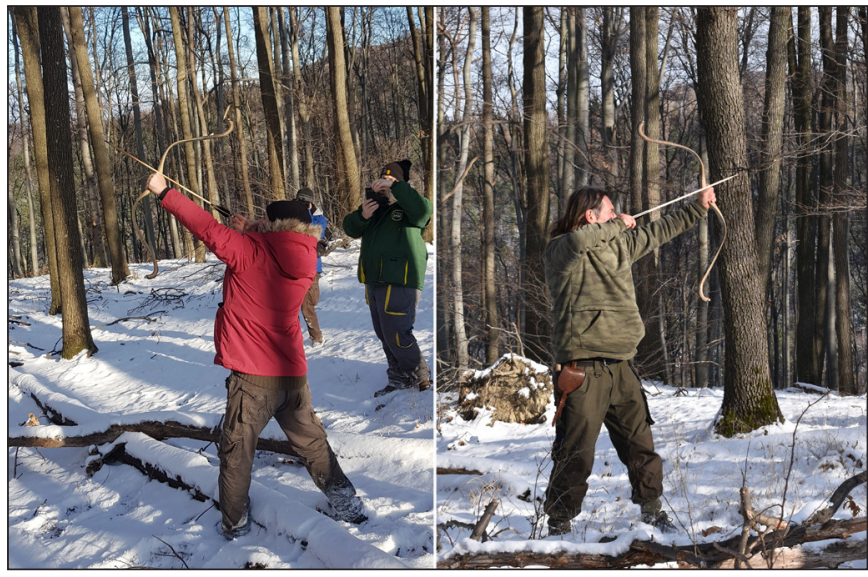

12. kép. Lövések a terepi kísérlet során

9 Egy olbiai felirat tanúsága szerint egy szkíta íjjal Dimagoras fia, Anaxagoras 282 orgyiai - kb. $500 \mathrm{~m}$ - távolságra lött el (BAKAS 2014; CUNLIFFE 2019, 239.). 
V. Szabó Gábor et al. • Rekonstruált szkíta kori íjakkal és nyilakkal végzett lökísérlet

\section{ÚJ ADATOK AZ OSTROM TÖRTÉNETÉHEZ - A KÍSÉRLET EREDMÉNYEI}

Összegzésképpen a következők mondhatók el kísérletünkröl: az ostrom egykori helyszínén általunk leadott lövések azt mutatták, hogy az erődítés hajdani cölöpfalai mögé belött nyilak maximum 100 méterre csapódtak be a kilövés helyétől. Ez azt bizonyíthatja, hogy a kora vaskori település belső részein, a sáncoktól 150-400 méterre talált nyílhegyek nem kintröl lettek belöve, hanem a falakon átjutó, az erődített település épületei közé behatoló ostromlók lövéseiből származnak.

Az ostromlók sikerére utalhatnak azok az összeégett, megolvadt, hétköznapi bronztárgyak is, amelyeket a fémkeresős kutatás során kerültek elő a sánc környezetében meghúzódó településrészeken. Hasonló szituáció figyelhető meg a smolenicemolpíri lelőhelyen is, ahol a település életének egy tüzvésszel együtt járó katasztrofális esemény vetett véget (Müller 2012, 248-250; Hellmuth 2017, 571-575).

A cölöpszerkezetről a nyilak egy része lepattant és szinte minden nyílhegy letört a becsapódás következtében. Egy nyílhegy 5 méterre is visszapattant, több nyílhegy pedig 1,5-2 $\mathrm{cm}$ mélységig beleállt a tölgyfába (13. kép). Közülük csak egyet sikerült kihúzni és megvizsgálni: a nyílhegyen nem találtuk semmilyen roncsolódás nyomát (14. kép).

A nyersbörrel borított vesszőfonat is hatásosan fogta fel a nyíllövéseket. A nyersbör nélküli sövénynyel szemben viszont mindhárom nyílhegytípus hatékony volt, a „2F” típusú hegyek teljesen át is ütötték. Mindössze egy „2B” típusú hegy csúcsán tapasztaltunk apró csorbulást.

A legtöbb elváltozást és sérülést a tömörített kavicsos, föld célfelületre kilött nyilak hegyein figyeltük meg. Bár a hegyek akár $21 \mathrm{~cm}$ mélységben is a földbe tudtak hatolni, a kétélü darabok csúcsából milliméteres darabok letörtek, egy kavicsba csapódó, „2F” típusú hegy csúcsa pedig jelentősen elhajlott (15. kép). A legtöbb nyílveszsző a köpü végénél letört a nyílhegyekröl, néhány vessző pedig épen esett ki a köpüböl becsapódáskor (16. kép), de az épen maradt földbe csapódott nyílvesszők hegye közül is több bent ragadt a földben a kihúzás során. A nyilak törésének az oka esetünkben az is lehetett, hogy a közeli lövések során, az ún. íjászparadoxon miatt kilengő nyilak kicsit oldalt csapódtak a célba.

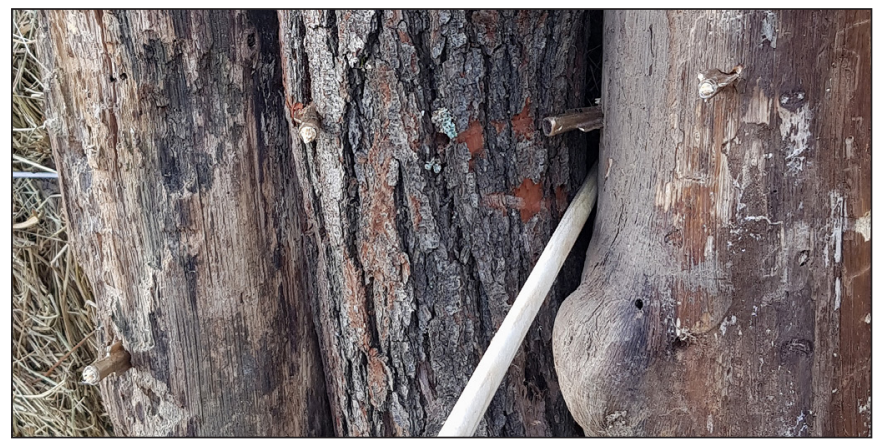

13. kép. A farönkökbe belelött, törött vesszöjü nyilhegyek

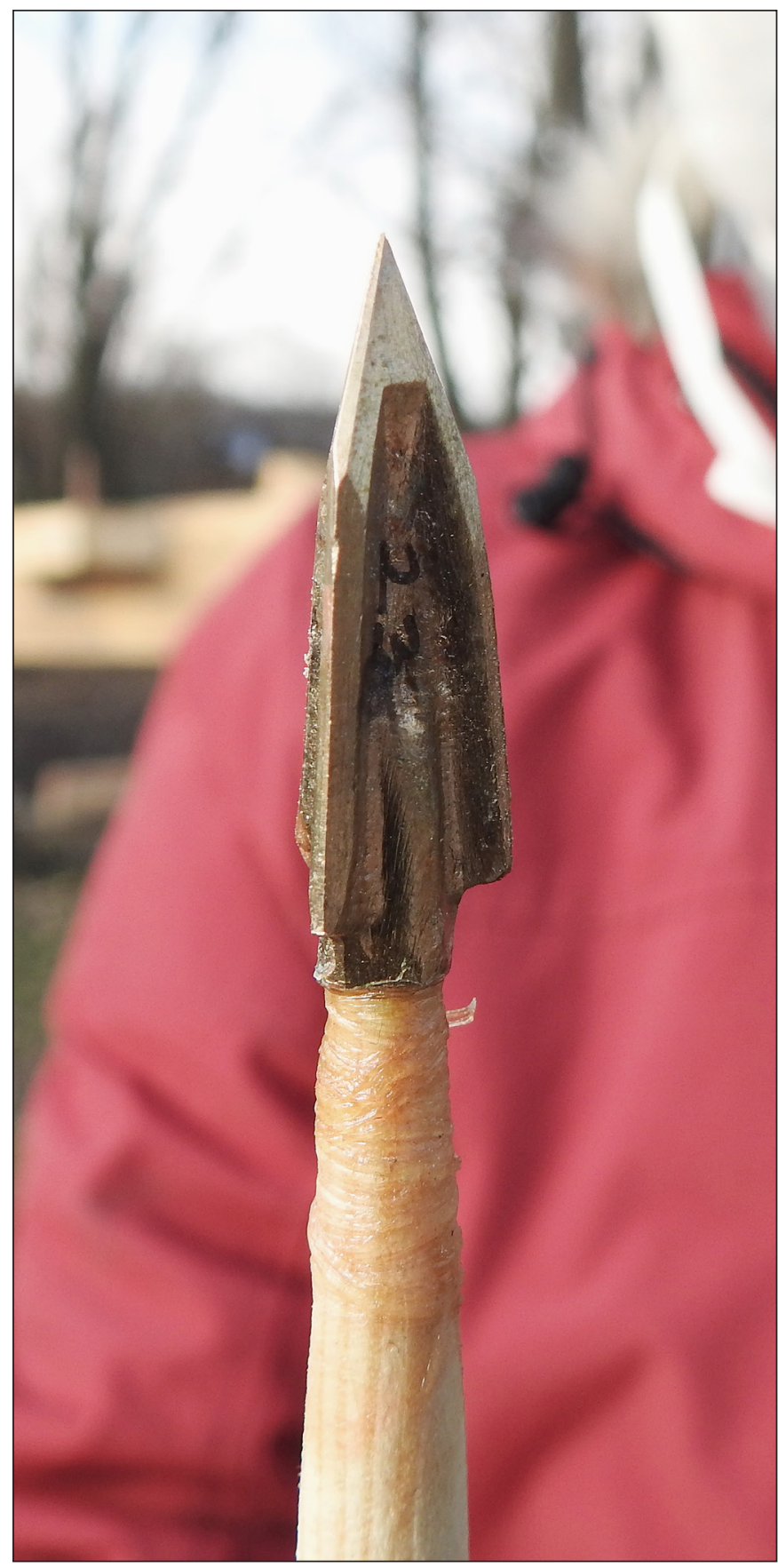

14. kép. A farönkökre kilött, sértetlen nyílvesszö 
V. Szabó Gábor et al. • Rekonstruált szkita kori íjakkal és nyilakkal végzett lökísérlet

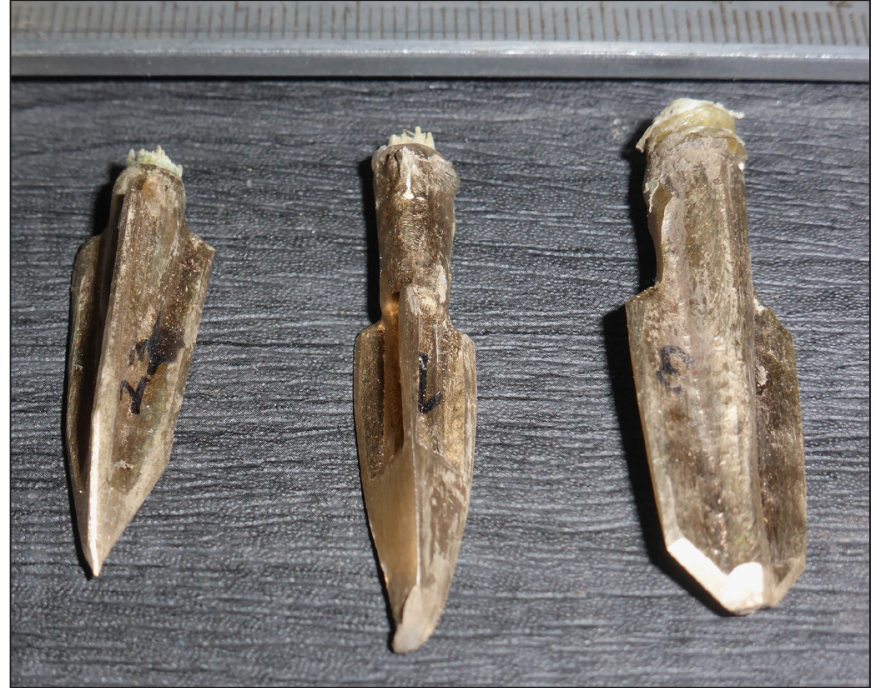

15. kép. A földet és kötörmeléket tartalmazó célfelületbe lött, sérült nyílhegyek

lezártnak: a jövőben a régióra jellemző, rövid nyilakkal szeretnénk kísérletezni, a vesszőket pedig megpróbáljuk a régészeti leletekből megismert fafajokból készíteni. Fontosnak tartjuk, hogy a folytatásban a nyílvesszők méretét és súlyát pontosabban összehangoljuk az íjak erejével, illetve azt, hogy a becsapódott nyílhegyek sérüléseit nagyobb, az eredeti távolságokhoz közelítő lötávról kilőve is megvizsgáljuk. ${ }^{10}$
A kísérlet próbalövései arra utalnak, hogy a támadás során kilőtt nyílhegyek jelentős része nem volt visszagyüjthető és újra felhasználható. Valószínüleg a sánc köves, tömörített földjébe fúródott nyílhegyek rongálódhattak és veszhettek el legnagyobb számban az ostrom során, de a törött nyílvesszők visszacsapódó darabjai sem voltak hiánytalanul visszagyüjthetők. Mindezek mellett sok nyílhegy szorulhatott a paliszád farönkjeibe vagy a szálfák réseibe, sok kilőtt darab pedig lepattanhatott a sáncárokba a falfelületről.

A cikkben bemutatott kutatást nem tekintjük

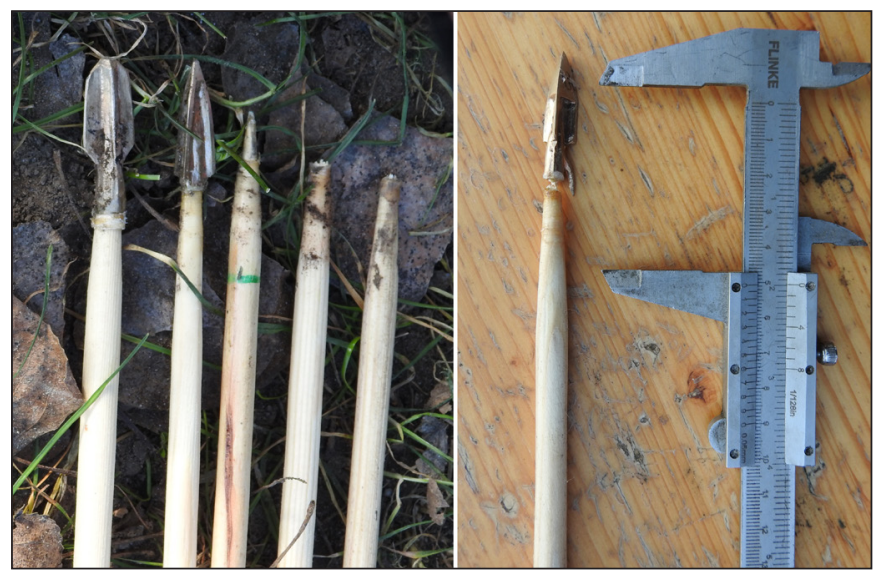

16. kép. A farönkökröl lepattant, sérült nyílvesszők

\section{IRODALOM}

Andruh, S. I. [Андрух, С. И.] (1988). Pogrebenyije rannyeszkifszkovo vojna v Priszivasje. [Погребение раннескифского воина в Присивашье]. Szovjetszkaja Arheologija 1 (1988), 159-170.

Bakas, S. (2013). Anaxagoras from Pontic Olbia. The first long-distance archery achievement recorded in history. https://koryvantes.blogspot.com/2013/06/anaxagoras-from-pontic-olbia-first-long.html Letöltés: 2021. 08.15.

Chochorowski, J. (2014). Scytowie a Europa Środkowa - historyczna interpretacja archeologicznej rzeczywistości. Die Skythen und Mitteleuropa - historische Deutung der archäologischen Wirklichkeit. Materiały i Sprawozdania Rzeszowskiego Ośrodka Archeologicznego XXXV (2014), 9-58.

Cunliffe, B. (2019). The Scythians: Nomad Warriors of the Steppe. Oxford: OUP.

Čugonov, K., Parzinger, H. \& Nagler, A. (2010). Die Gräber und ihre Funde. In: K. Čugonov, H. Parzinger \& A. Nagler (Hrsg.), Der skythenzeitliche Fürstengrab Aržan in Tuva (pp. 217-231). Archäologie in Eurasien Bd. 26, Steppenvölker Eurasiens 3. Mainz: von Zabern.

10 A kutatást az NKFI 138768 számú pályázata támogatta. 
V. Szabó Gábor et al. • Rekonstruált szkita kori íjakkal és nyilakkal végzett lökísérlet

Daragan, M. N. (2020a). Scythian leather quiver from Bulgakovo. Ancient Civilizations from Scythia to Siberia 26 (2020), 146-171. https://doi.org/10.1163/15700577-12341361

Daragan, M. N. (2020b). Scythian archers of the 4th century BC: A new archaeological study of excavated bows, arrowsand quivers from the northern Black Sea region. In: S. Pankova \& St. J. Simpson (eds), Masters of the Steppe: The Impact of the Scythians and Later Nomad Societies of Eurasia (pp. 103-124). Oxford: Archaeopress. https://doi.org/10.2307/j.ctv1fcf8hh.14

Daragan, M. N. \& Romanenko, Y. N. (2021): Technique and technology of Scythian bronze arrowhead casting: Experimental and metallographic approach. Journal of Archaeological Science: Reports 37 (2021), 102919. https://doi.org/10.1016/j.jasrep.2021.102919

Dweyr, B. (2003). Schythian-style bows discovered in Xinjiang. Journal of the Society of Archer Antiquaries 48 (2003), 71-82.

Godehardt, D., Godehardt, E. \& Schellenberg, H. M. (2009). Der skytische Bogen. In: V. Alles (Hrsg.), Reflexbogen - Geschichte und Herstellung (pp. 26-59). Ludwigshafen.

Godehardt, E. \& Schellenberg, H. M. (2010). Der Bogenfund aus Grab 5 und Überlegungen zu skythenzeitlichen Bögen. In: K. Čugonov, H. Parzinger \& A. Nagler (Hrsg.), Der skythenzeitliche Fürstengrab Aržan in Tuva (pp. 217-231). Archäologie in Eurasien 26, Steppenvölker Eurasiens 3. Mainz: von Zabern.

Hellmuth, A. (2010). Bogenschützen des Pontischen Raumes in der Älteren Eisenzeit. Typologische Gliederung, Verbreitung und Chronologie der skythischen Pfeilspitzen. Universitätsforschungen zur prähistorischen Archäologie 177. Bonn: Habelt.

Hellmuth-Kranberger, A. (2017). Archäologische Hinweise zu kriegerischen Auseinandersetzungen mit reiternomadischen Gruppen im östlichen Mitteleuropa und im Vorderen Orient. In: E. Miroššayová, C. Pare \& S. Stegmann-Rajtár (Hrsg.), Das nördliche Karpathenbecken in der Hallstattzeit: Wirtschaft, Handel und Kommunikation in früheisenzeitlichen Gesellschaften zwischen Ostalpen und Westpannonien (pp. 571589). Budapest: Archaeolingua.

Karpowicz, A. \& Selby, S. (2010). Scythian bow from Xinjang. Journal of the Society of Archer Antiquaries 53 (2010), 94-102.

Kiss A. (2020). ,Ijuk, mint isten karja, és nyilaik elől nincs menekvés.” Sztyeppei típusú szaru-ín összetett ijak és nyílvesszők használati értékének vizsgálata. - "Their bow like God's arm, no escape from their arrows". The examination of the value in use of steppe-type horn-tendon bows and arrows. Hadtörténelmi Közlemények 133/4 (2020), 953-997.

Klápa, O. (2017). "Schythian" findings in the Moravia. Acta Archaeologica Carpathica 52 (2017) 65-82.

Lukjasko, Sz. I. [Лукьяшко С. И.] (2015). Scythicus acrus. Sztrelkovoje oruzsije szkifov 1. [Стрелковое оружие скифов 1.] Nauka Juga Rosszii (Vesztnyik Juzsnovo Naucsnovo Centra) 11/4 (2015), 87-92.

Lukjasko, Sz. I. [Лукьяшко С. И.] (2016). Scythicus acrus. Sztrelkovoje oruzsije szkifov 2. [Стрелковое оружие скифов 2.] Nauka Juga Rosszii (Vesztnyik Juzsnovo Naucsnovo Centra) 12/1 (2016), 84-92. 
V. Szabó Gábor et al. • Rekonstruált szkita kori íjakkal és nyilakkal végzett lökísérlet

Müller, S. (2012). Smolenice-Molpír, Sered' und Ratkovce: Studien zu Siedlungen der frühen Eisenzeit in der Südwestslowakei. Universitätsforschungen zur Prähistorischen Archäologie 220. Bonn: Habelt.

Novák, M. (2017). Moravsky „Molpír“? Halštatske nalezy z opevněneho vyšinneho sidliště ProvodovLudkovice „Rysov“ (okr. Zlin). - Moravian “Molpír”? Hallstatt period finds from fortified hilltop settlement Provodov-Ludkovice "Rysov” (Zlín District). Pravěk Nova řada 25, (2017) 185-228.

Riesch, H. \& Rutschke, J. (2009). Der Subexi-Bogen in der Ausstellung „Ursprünge der Seidenstraße“. In: V. Alles (Hrsg.), Reflexbogen - Geschichte und Herstellung (pp. 60-69). Ludwigshafen.

V. Szabó, G. (2018). Nyílzáporban. Egy kora vaskori hadjárat emlékei a Kárpát-medencében. Határtalan Régészet - Archeológiai Magazin 3/1 (2018), 58-62.

V. Szabó, G., Czajlik, Z. \& Reményi, L. (2014). Egy vaskori fegyveres konfliktus nyomai. Új topográfiai eredmények a dédestapolcsányi Verebce-tető kutatásában I. Magyar Régészet 3/1 [2014 tavasz], 1-6. http:// files.archaeolingua.hu/2014TA/Upload/Szabo_14TA.pdf Letöltés: 2021.10.20.

Taylor, W., Hart, I., Pan, C., Bayarsaikhan, J., Murdoch, J., Caspari, G. et al. (2021). High altitude hunting, climate change, and pastoral resilience in eastern Eurasia. Scientific Reports 11/14287 (2021). https://doi. org/10.1038/s41598-021-93765-W 